\title{
第23回 日本門脈圧六進症研究会抄録
}

\author{
会 期: 平成 2 年 9 月29日（土） \\ 会 場: ホテルキャッスルブラザ \\ 世話人:高木 弘 (名古屋大学医学部第 2 外科)
}

\section{主題 I 食道静脈瘤治療の予後}

\section{1. 食道静脈瘤直達手術後の予後}

山形大学第 1 外科

瀬尾 伸夫, 石山 秀一，布施 明

佐藤淳, 安達 和仁, 五十峲幸夫

西山宗一郎, 須藤 幸一，塚本 長

食道静脈瘤直達手術耐術例68例(肝硬变症56例, IPH 12例）を対象とした。術式別静脈瘤再発率は杉浦法9/

51, Hassab 手術 $3 / 13$, 経胸食道離断のみ0/4で, 10 例 にEISを追加した. 生存率はIPHでは 5 年, 10 年とも $92 \%$, 肝硬変症では 5 年 $67 \%, 10$ 年38\%で, 死因は肝 不全11例, 肝細胞癌 7 例, その他 8 例で, 消化管出血 は2 例たけであった。一方，肝細胞癌は18例にみられ， 累積発生率は 5 年 $27 \% ， 10$ 年 $57 \%$ と高率であった。定 期検診受診者では 8 例の肝細胞癌が発見されたか， 7 例が切除可能の状態で 6 例切除し，5例は生存中であ る.手術, EISに上り、静眽瘤出血はコントロールされ ているが，定期検診による肝細胞癌の早期発見が予後 向上には重要である.

\section{Child $B / C$ 症例に対する直達手術一遠隔成 績からみた検討}

岩手医科大学医学部第 1 外科

中村 隆二, 渡辺 正敏, 杉村 好彦

松野 伸哉, 菊池 充, 斉藤 和好

最近12年間の肝硬変合併食道静脈瘤に対する直達手 術症例を，標準手術群（開胸・開腹・血行郭清・食道 離断術) と樎小手術群（経腹的食道離断または Hassab 手術)に大別し，各群でChild 分類 BまたはCの症例 (B/C 群) の遠隔成績をChild A 症例（A 群）上比較 挨討した。標準手術群では B/C 群 (36例) は $A$ 群 (51 例) 症例に比へてて再発率に有意差はないが， 3 年以降 の生存率が有意に低下し，肝癌，肝不全が死因として 多かった，縮小手術群では $B / C$ 症例 ( 9 例) は肝癌合 併例，高度肝機能障害例が早期に死亡したが胃静脈瘤
例は比較的長期生存した，B/C症例では胃静脈瘤症例 がよい手術適芯があり，また肝癌死亡例の割合が高い ことから，術後肝癌発生の早期発見が予後向上に大切 である.

\section{Hassab 手術の予後と問題点}

聖マリアンナ医科大学第 1 外科

$\begin{array}{rrrr}\text { 中野 } & \text { 末広, 萩原 } & \text { 優, 酒井 } & \text { 昌博 } \\ \text { 長岡 } & \text { 至郎, 岡野 } & \text { 亨, 猪狩 } & \text { 次郎 } \\ \text { 守屋 } & \text { 上布, 窪田 } & \text { 倭, 片山 } & \text { 憲恃 } \\ \text { 山口 } & \text { 晋, 片埸 } & \text { 嘉明, 渡边 } & \text { 弘 }\end{array}$

近年, 食道静脈瘤の治療が内視鏡的硬化療法が普及 した為に治療体系の変化を来たしている，特に直達街 の一つである Hassab 手術例が再評価されている， こで，教室で経験した同手術例を検討した。

症例数は直達術145例中10例 $7 \%$ である。男女比は $1 ： 1$, 平均年齡55歳, 原疾患は肝硬变 7 例, IPH 3 例, 手術時期は予防 6 例, 待期 3 例, 緊急 1 例, Child 分類ではA 2 例, B 7 例，C 1 例であった. 手術死亡 はChild Cの緊急例の 1 例であった。

Hassab は安全性が高く, 胃静脈瘤は75\%が消失，食 道静脈瘤に関しては半数の症例で F 因子又は RC sign の軽快が得られたに過ぎなかった。

\section{4. 食道静脈瘤に対する各種治療の評価 大分医科大学第 1 外科 \\ 御手洗義信, 吉田 隆典, 坂東登志雄 中島 公洋, 吉村 高尚, 長峰 健二 小林 迪夫}

食道静脈瘤の各種治療の成績と再発の対策について 検討した。対象は, 食道静脈瘤症例の147例(手術89例, 硬化㞠法：ST 87例, 両者の併用29例)である。その結 果, ST 単独例の再発率は19.6\%, 再出血率は9.8\%で あった。手術療法のらち、シャント手術43例の再発は 
$16.3 \%$, 再出血率 $2.3 \%$, 食道離断術23例の再発率は $13.0 \%$ ，再出血率4.3\%であっだ，一方ジャント手行 や食道離断術の再発の要因として，左胃静脈の血行動 態が遠肝性の症例に再発が多い傾向にあった。このこ とを考慮にいれ，訹後静脈瘤の遺残に対しては，早期 にSTを追加し静脈慮を消失させるよ5にしている。 これにより, 手術十早期硬化療法の 5 年累積生存率は $80 \%$ 以上と良好な成績を示した，以上，手術と積極的 なST 併用の有用性について述ぺた。

\section{5. 肝硬変食道静脈痛症例に対する直達手術と} 効果療法の予後

新潟大学第 1 外科

$$
\begin{aligned}
& \text { 塚田 一博, 長谷川 滋 } \\
& \text { 吉田 奎介, 武藤 旿一 }
\end{aligned}
$$

本年 3 月までの食道静脈㳅症例378例のうち PBC 除く肝硬変症の予後をその初回治療法により直達手 訹群之硬化療法群にわけ比較した，症例は直達手術群 120例之硬化療法97例で他治㞠併用例がそれぞれ 6 例, 10例含饥ていた，CHILD 分類別では A が57例，24 例，B が41例，44例，C が22例，29例であった．治療時 期別では掔急治療か２8例，32例，待期治療が51例，33 例で予防治療は41例，32例であった．1 カ月以内死亡 は直達手術 7 例，硬化㞠法 5 例で， 5 年累積生存率は それぞれ50.6\%，42\%と差はなかった. CHILD 分類別 では A，B，Cのあいたに差を認めた。遠隔時死亡原因 では直達手術群に肝癌が硬化療法群に出血に起因する むのが多かった．治療法により死因に差がみられたが 長期予後住それぞれの肝予備能に負らところが大と考 えられた。

\section{6. 各種食道静脤嘴治療の予後}

順天堂大学第 2 外科

$$
\begin{aligned}
& \text { 木下 策一, 平出 康隆, 大浦 傎㤑 } \\
& \text { 丸山 俊朗，本間 侯，太田秀二郎 } \\
& \text { 児島 邦明，深澤 正樹，別府 倫兄 } \\
& \text { 二川 绤二 }
\end{aligned}
$$

1979年 9 月より1990年 7 月までに順天堂大学第 2 外 科にて治療を行った食道静脈瘁544例についてての治 㞠効果と予後について検討した，我々が施行した各種 治療法は経胸食道漓断術, 内視鏡的硬化療法, Hassab 手街, 経腹食道離断術, 硬化㞠法と Hassab 手術または 経腹離断術の combined therapyであった。
有效性が最る良好であった治療法は経胸食道離断術 （杉浦法）であり371例に行い静脈痊消失效果は消失俥圣 块 $98 \%$ ，遗残再発 $14 \%$ ，再出血 $7 \%, 10$ 年生存率 Child A 68\%, Child B 56\%, Child C 24\%であった。食道 静脈瘤症例には状態が許せば経胸離断術が第一選択で あり, Child CP肝癌併存例は長期生存が難しいため 状況に応した治療法を選択すべきである。

\section{7. 食道静脈瘤治療の予後一食道離断術と内視 鏡的硬化癔法の比較一}

兵庫医科大学第 1 外科

井上 晃男, 岡本 英三, 豊坂 昭弘

中井 謙之, 富本 喜文, 石川 英明

大阪第二警察病院外科朱 明義

当教室において1990年 9月まてに，食道静脈㨨に対 して手術を181例，内視鏡的硬化療法(以下 EIS)を414 例に施行した，今回静脈瘤に対する治療成績を retrospective に検討した結果以下のごとく治療方針を確 立した，当教室の治療方針は，1）緊急例は, EISにて 止血を得た後、旰機能評価を行い手術かEISによる follow かを決定している，2）特発性門脈王六進症や， 著明な脾腫，脾機能六進症を伴 5 Child A，B の肝便 変症例は手術を第一選択としている，3）他は，静脈瘤 の完全消失を目標に硬化㞠法を行い敞重な follow と 追加硬化療法を施行している。

\section{8. 食道静脈瘤治療の予後}

日本医科大学第 1 外科

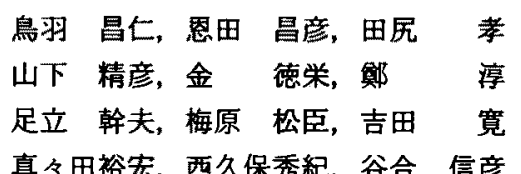

教室では，婜急出血例および poor risk 症例に対し 各種血管塞栓術を組み合わせることで保存的に治療し ており緊急止血率は $100 \%$ でる。内視鏡的硬化療法 (EIS) ではとくに術後遭残再発例, 各種塞栓㭪併施例 において追加治療までの期間および出血率ともに EIS 単独に教へてその成縝は良好であった。，一方，手術療 法では1986年より手術適応基準を設定しこれに即して DSRSを中心に施行しているがその35症例の予後は術 死は門脈血栓の 1 例のみで再出血はなく現在生存中の 29例は PS 0 が19例, PS 1 が10例で充分社会復㷌して おり再治療は全く行われていない。 
9. Hassab 変法手術十硬化療法の奻果と予後 東京慈恵会医科大学第 2 外科

$$
\begin{aligned}
& \text { 稲垣 芳則, 岩崎 貴, 関口 } \text { 更一 } \\
& \text { 佐野 勝英, 石井 雄二, 恩田 啓二 } \\
& \text { 岡本 友好, 中里 雄一, 中村 純太 } \\
& \text { 中本 実, 青木 照明 }
\end{aligned}
$$

教室では Hassab 変法+EIS（術後 3 週前後）を48例 に施行しその効果と予後を険討した，治療対象は LC 40, IPH 6, EHO 2で Child A 20, B 21, C 3, 手術 は予防 18 ，待期30例であった。 Hassab 手術終了時の術 中内視鏡で静脈瘤の消失はなく，不変 3 例以外はFの 軽減を認めた. EIS は平均2.8回で75\%に消失, $\mathrm{F}_{1}$ 以下 の遺残23\%であった，退院後の追加 EIS では平均 1.6 月後に2.2回で94\%に消失した，他治療と比較し EIS 単独より良好であり，食道離断とは济同様であった。 また術後障害は食道離断より良好であった。予後は 2 例に食道静脈瘤出血，1例に胃炎出血を来し HCC 3, 肝不全 2 例死亡したが，他は現在まで良好である。

\section{0. 選択的遠位膢腎静脈吻合術施行例の予後} 札幌北柡病院外科

米川 元樹, 目黒 順一

Henryk Witmanowski 久木田和丘, 川村 明夫 北海道大学第 1 外科

$$
\begin{array}{rrr}
\text { 武田 } & \text { 圭佐, 高橋 } & \text { 昌宏 } \\
\text { 旭川医科大学第 } 2 \text { 外科 } & \text { 古井 秀典 }
\end{array}
$$

食道静脈瘤16例に選択的遠位脾腎静脈吻合術を施行 した、いずれも乙型もしくは乙型肝硬変を有し、Child A 12例，B 3 例，C 1 例であった。吐血歴を有する症 例は 7 例で内 2 例は緊急例であった。術後は重篤な合 併症や再吐血はなく，全例内視鏡所見の改善をみた。 Child 分類別に生存率をみるとA群12例中11例 (91.7\%)，B 群 3 例中 1 例 $(33.3 \%) ， \mathrm{C}$ 群 1 例中 0 (0\%)で，死亡例 4 例は術後 3 力月から 1 年 4 力月の 間にいずれも肝不全により死亡して括り，予後はもっ ばら肝硬变の程度に依存していた，生存例は 12 例，最 長 4 年11カ月で，いずれも MRIによりシャント部の 開存が確認されており，予後が期待される。

\section{1. 食道静脈瘤治療の予後}

日本大学医学部第 1 外科

$$
\text { 大野誠, 七木 基裕, 岩瀬 正明 }
$$

三宅 洋, 都築 秀至, 天野 定雄

丹正 勝久, 黑須 康彦, 森田 建

教室では高度肝機能障害や手術拒否症例の食道静脈 瘤症例に対し，系統的門脈側副路塞栓術を行っている。 今回本法の出血例について検討した。74症例中出血は 21例，胃出血は12例，保存療法で 7 例は止血，5例は 肝不全併発し死亡した。 2 例の剖検にて胃粘膜の組織 像より Portal hypertensive gastropathy に相当する 所見が得られた。この点より1988年以降はGastropathy の所見に注目し現在薬物療法として $\beta_{2}$. Blocker Nadolol を投与し最長 1 年 6 力月, 平均 11 力 月経過観察中であり現在まで出血，合併症等みられて いない. Nadolol の投与は門脈圧六進症に伴ら胃粘膜 病変に対して有効で, 患者そのものの予後の向上に重 要であることを報告した。

\section{2. 長期予後からみた内視鏡的硬化療法の成績} 東京女子医科大学第二病院外科

$$
\begin{aligned}
& \text { 成高 義彦, 小川 健治, 矢川 裕一 } \\
& \text { 島川武，腾部 隆男，渡辺 俊明 } \\
& \text { 芳賀 駿介，旌原 哲郎 }
\end{aligned}
$$

過去 9 年 9 カ月間に当科で程験した硬化㞠法は261 例の延べ734回である，硬化療法は5\%EOによる血管 内注入法を原則とした。

累積生存率は全症例で 1 年79\%，3 年61\%，5年 $49 \%, 8$ 年 $41 \%$ であり，㗨急例, 肝癌合併例, Child C 症例の予後は有意に不良であった。死亡した 98 例の死 因は肝不全, 肝癌死などが主で, 静脈瘤出血死は 6 例 であった。

再出血は 53 例 $(20.0 \%)$ にみられ，その特徵は発赤 所見の残存再発および胃静脈瘤出血の増加であり，累 積出血率は 1 年 $14 \%, 3$ 年 $25 \%, 5$ 年33\%，8 年 $43 \%$ であった，硬化療法を繰り返すことにより食道静脈瘤 は制御可能と考えるが，胃静脈㿔の一部には限界があ り，耐術例であれば手術，肝機能不良例には Histoacryl による硬化療法で良好な結果を得ている。

\section{3. 予後からみた予防的硬化療法の是否一予防 的硬化療法道入前と後での比較検討一 奈良罧立医科大学第 3 内科 \\ 本田 泰啓, 松村 雅彦，小泉 雅紀 小㟽 秀之, 松為 裕二, 山本浩 福井博, 辻井正}


近年, 内視鏡的食道静脈瘤硬化㞠法 (EIS) の普及に より静脈嘴出血死の頻度江激减傾向にある。しかし， 予防的 EIS の是否については一定の見解が得られて いない，そこで今回予防的 EIS 施行例と EIS 導入前の 静脈瘤症例との予後を比較することにより，予防的 EISの是否につき険討し，以下の結論を得た，1）予防 的 EIS 施行により累積出血率及び累積出血死亡率は 著しく低下した．2）出血予防期間はおおむね24カ月と 考えられた.3）高度肝障害例においても出血予防効果 は十分に期待できるが，肝癌合併例では出血予防効果 は少ないと考古られた.4）十分な出血予防効果を得る ために EIS 終了点を消失又は扁平・島状・索状の形態 にすることが必要と考えられた。

\section{4. 初回治㞠時の Child 分類と硬化療法啳の食} 道静脈瘦再発治癔時期との関保

旭川医科大学第 3 内科

富永 吉春, 矢崎 康幸, 村住ゆかり

村住 和彦，太田 人可，大平 基之

大平 賀子，幸田 弘信，小野 稳

長谷部千登美, 池田 直治, 関谷 干尋

並木 正義

内視鏡的硬化療法（以下 EIS）にて一旦完全消失した 後に食道静脈瘤の再発をきたし再治療を行った42例に つ初回治療時 Child 分類之再発静脈瘤の治療時期之 の関係を検討した１2力月以内の早期再発をきたした 症例 (17例)の5ち14例 (82\%) は初回治療時 Child B またはCであった。これに対し25カ月以降の啳期再発 例は14例あったが，このうち12例（86\%）は初回治㞠 時 Child A の症例であった. EISにより一旦完全消失 した食道静脈瘤も肝病変の進展した症例においては比 㜞的早期に再発をきたすことがあり，慎重な経過観察 とすみやかな追加治㞠が必要である.

\section{5. 食道静脈瘦硬化療法後の自覚症状の長期観} 察の検討（アンケート調查による）

昭和大学藤が丘病院消化器内科

$\begin{array}{lll}\text { 鉿木 悟司, 高橋 寛, 杉山 } & \text { 主一 } \\ \text { 光銭 健三, 関 盛使, 你 儀治 } \\ \text { 藤田 力也, 营田 } \\ \text { 文夫 }\end{array}$

食道静脈瘤硬化療法 (EIS) 施行症例の増加にともな いEIS 後に食道謴瘍を形成し胸やけや胸骨後方部痛 などを訴える症例を释験するよらになった。これらの
症例に対して，胸やけ，食道のしみる感し，胸骨後方 部痛などについてフンケート調查を行なった，その結 果, 胸やけ感やしみろ感しなどの逆流性食道炎様㱏状 を認める症例が最も多く72\%を占めていた。これらの 自覚症状は, EIS 終了後約 8 時間以内に消失していた。 また我々は，EIS 前後およぴ 6 力月後の下部食道括約 筋王 (LESP) を測定し，下部食道括約筋逆流防止機構 に与える影響む测定しているが，EIS 直後に LESP は，一時的には低下を認めたが 6 カ月後には回復が認 められた。

16. TAE 施行肝癌例の長期予後一予防的硬化 療法の意義について 虎の門病院消化器科

村島 直哉, 田中 達朗 竹内 和男, 中島 正男

対象・方法：繰り返しTAEを施行した肝細胞湜94 例を，食道静脈瘤が高度で硬化療法を施行した 32 例(予 防22・特期 7 ・緊急 3) と, 静脈瘤がないか軽硬 化療法不要と判定された62例とに分け，生存率・死因 を比較した。

成績：両群間で生存率の有意な差はなかった，臨床 期分類別にみると，予防的硬化療法群の 2 年生存率は, Stage I・IIでそれぞれ100\%・81.8\%で，硬化㞠法不 要群の $57.6 \% \cdot 50.0 \%$ をまわっていた。硬化潦法群 の死因では，静脈瘤からの出血死は 2 例（全死亡の 9.1\%)と少なかった.

結語：切除不能肝癌では，予防的硬化療法に上り， 出血に上る死亡の增加を妨げていると推定された。

\section{7. 肝癌合併食道静脈瘤に対する内視鏡的硬化 療法施行例の予啳}

旭川医科大学第 3 内科

川島 哲也，矢崎 康幸，富永 吉春

辻 邦彦, 山田 政孝, 鈴木 貴久

闺谷 千尋，並木 正義

内視鏡的硬化療法(以下 EIS)を施行した肝癌合併肝 硬変40例を次の 4 群に分けて検討した。 コントロール 良好な 1 要区域以内の単発肝癌を I 群( 2 例)，コント ロール良好な多発性肝癌をII群 ( 8 例)，急速発有する 肝癌で治療困難なるのを等群(15例)，肝癌コントロー ル良好たが肝硬变が急速に進展したものをIV群(15例) とした，経過中静脈瘤出血を，II群中 7 例(47\%)，IV 
群中 3 例（20\%）にみた。これらの群では EIS 施行後 も再発しやすく，特に林群で短期間でみられた。 また 再発静脈㿔からの出血は $F_{1} R C(+)$ からのbのだっ た、肝癌合併症例に対してる積極的に適切な EISを追 加することにより静脈瘤出血は予防できると考えられ た.

18. 術前硬化療法を施行した肝癌合併肝硬变症 例の検討

日本大学第 3 外科

$\begin{array}{lllll}\text { 須田 清美, 高野 } & \text { 靖悟, 佐藤 } & \text { 博信 } \\ \text { 村山 } \quad \text { 公, 森 } & \text { 洋幸, 大梘 } & \text { 諡治 } \\ \text { 奥脇秀一郎, 河野 } & \text { 悟, 鈴木 } & \text { 武樹 } \\ \text { 田中 隆 } & & & \end{array}$

1985年10月より1990年 5 月までに当教室に入院した 旰細胞癌症例は149例である。この5ち83例 (55.7\%) に肝切除を施行し，TAE を32症例 (21.5\%) に施行し た。肝切除症例中食道静脈瘤を合併していた症例は 9

例，TAE 施行例では 6 例に食道静脈瘤を合併してい た. 肝切除例の食道静脈瘤に対して術前硬化療法を施 行したのは 9 症例であった。一方 TAE 施行例の食道 静脈瘤に対して硬化療法を 6 例に施行した。 今回切除 例之 TAE 施行例に対する硬化療法施行症例の治療成
績と予後について比較检討したので報告した。

19. Color Doppler 断層法を用いた食道静脈瘤 硬化療法後の門脈血行動態の観察（長期踲察 例の検討）

$$
\begin{array}{llll}
\text { 昭和大学第 } 2 \text { 内科 } & & \\
\text { 米山啓一郎, 石井 } & \text { 誠, 桷口 } & \text { 健一 } \\
\text { 加藤 和夫, 小貫 } & \text { 誠, 八田 善夫 }
\end{array}
$$

目的: 食道静脈瘤硬化療法 (EIS) 後の門脈血流变化 について検討を行った。

対象と方法：EIS 前後で Color Doppler 断層法を用 い1 3 年門脈血行動熊を観察し得た肝硬变15例を対 象とした。

結果の要約：1) EIS 後の門脈血流変化は早期では 脾門部脾静脈の血流增加と脾腫が認められ，1 年以上 では脾門部脾静脈血流量増加は 2 年がピークで, 脾腫 は3カ月がビークであった。 また，右門脈の血流量は 殆ど変化を認めなかった，2）EIS 良好例では脾門部脾 静脈血流量増加之脾腫増大が早期より出現していた。 3）脾門部近傍シャント形成や傍㷙静脈開大例ほど, EISの効果が良好であった，4）EISの効果の検討には 内視鏡的な食道静脈瘤の变化だけでなく門脈血行動態 の把握が重要である.

\section{主題II 門脈圧光進症と循環動態}

20. 硬変性門脈圧え進症の病態と肝および全身 血行動態の関釈

日本医科大学第 1 内科

関山 達也, 黒川 浩史, 長野 具雄

筒井 七, 古明地弘和，大須賀 勝

寺田 秀人，里村 克章，勝田 悌実

荒牧 㻟己，奥村 英正

肝硬变156例において肝および全身血行動態と病態， とくに食道静脈瘤（EV）の関連を検討した，慢性肝炎 46例を対照とした。

結果・断案：慢性肝炎 (CH) に比し肝硬変では肝静 脈妿入臣 (WHVP), 肝静脈王較差 (HVPG)，心拍出 量 (CO), 循珙血量 (PV) は有意に上昇, 総末梢血 管抵抗（TSVR）は有意に低下した。肝硬変において Child-Pugh 分類 C では A に比し HVPG，心保数が有
意に高値であった，EVのF因子に関しその增大に伴 いCO，PVは上昇，TSVRは低下，WHVP，HVPG は増加した。一方, EV の占居部位ではその拡大に伴い PV, CO の増加傾向，TSVRの低下傾向がみられたが 有意ではなかった，しかし WHVP，HVPGは有意に 増加した，以上より $\mathrm{F}$ 因子之全身血行動態，とくに hyperdynamic circulation との関保が示唆された。

\section{1. 門六症における術前後の血行動態について 山形大学第 1 外科布施 明}

門六症患者に対する開腹術後の血行動態をSwanGanz catheter を用い検討した。肝硬变群とIPH 群で 比較検討し，さらに, dobutamine 投与による影響を検 討した。

IPH 群では術後心係数 (CI) が増加傎向を示し, 分 
時酸素運搬量 $\left(\mathrm{O}_{2}\right.$ delivery $)$, 酸素消費量 $\left(\dot{\mathrm{VO}}_{2}\right)$ が訹 後有意に増加した。これに対し，肝硬変群では $\mathrm{CI}, \mathrm{O}_{2}$ delivery, $\mathrm{VO}_{2}$ がいずれる有意の增加を示さず, 酸素需 給状態は不良であった。肝硬变症例に術直後より dobutamine を投与すると, $\mathrm{CI}, \dot{\mathrm{VO}}_{2}, \mathrm{O}_{2}$ delivery が 有意の增加ないしは增加㑯向を示した。 dobutamine 投与により術後 ICG 消失率の低下を予防 できた。したがって，肝硬変症例に対する術後の dobutamine 投与は, 全身の循環動態, 酸素需給状態の 改善, さらに有效肝血流量維持の点で有用である。

\section{2. 肝硬变症における肝循環動龍と肝切除に伴} う変化

$$
\begin{aligned}
& \text { 名古屋大学第 } 2 \text { 外科 }{ }^{11} \text { ，同 麻醉科 }{ }^{21} \\
& \text { 伊藤 隆文”野浪敏明, 原田 明生 } \\
& \text { 黒川 㓮, 氏田 剛, 小林 裕幸 } \\
& \text { 岸本 若彦, 中尾 昭公, 貝沼 関志") } \\
& \text { 高木 弘" }
\end{aligned}
$$

我々は肝硬変症の全身血行動態における hyperdynamic state の代儥的意義及び術後低濃度 cathecholamine 投与の有用性について報告してきた。今回 旰切除14症例（肝硬変 7 例，非硬変 7 例）において超 音波血流計を用いて肝切除前後における肝循環及び酸 素需給動態の検討を行った，その結果肝硬変症例は全 身循環動態において hyperdynamic state を呈すがー 方肝循㻴動態に打いては肝血流量の低下, 酸素供給量 の低下等を認めた。これに対して dobutamine 投与の 効果について肝切除前後で梌討した結果肝硬変症例に おいても肝循瓄及び酸素需給動態の改善が認められ た.

\section{3. 食道静脈瘤と局所の循環動態の検討}

\section{群馬大学医学部第 1 外科服部 徳昭}

腹腔動脈撮影, 菜物学的上腸間膜動脈熶影を施行し た症例の中から、門脈圧六進症をきたす疾患90例を選 び, 吐血の有無, 側副血行路の有無から 3 群に分けた。 各群について, 食道静脈瘤, 側副血行路, 性差, 年龄, 基礎疾患，脾睡を検討した。

食道静脈瘤の形成には胃冠状静脈, 短胃静脈を介す る側副血行路の関与が認められた。脾腎静脈系シャン トが単独にあるすのでは, 食道静脈留の形成は $22 \%$ と 少ないか，脾堅静脈系シャントがあっても胃冠状静脈 の側副血行が認めら九るすのでは40\%に食道静脈瘤が
認められた。 また，吐血例では肝硬変患者が多く，脾 腫の頻度も多かった。また脾腎静脈禾シャントが単独 で認められるもので約 $30 \%$ に内視鏡で食道静脈㿔が認 められた。

\section{4. 門脈圧え進症の循僼動龍一殊に成人型肝外} 門脈閉塞症について NTT 札幌病院外科

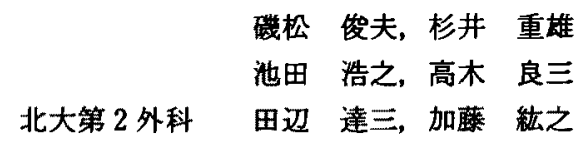

検討症例の内訳：一次性は男性 $3 \cdot$ 平均年龄 $50 \pm 17$ 歳, 女性 7 平均年龄 $33 \pm 10$ 歳, 肝組織所見は正常 3 旰 織維化 4 慢性肝炎 3 . 二次性の 5 例は男性・平均年龄 46士13歳であった，血行動態的に，一次性では門脈王 $302 \pm 63 \mathrm{mmH}_{2} \mathrm{O}$, 閉塞肝静脈王 $110 \pm 25 \mathrm{mmH}_{2} \mathrm{O}$, 胃壁 静脈压 $110 \pm 25 \mathrm{mmH}_{2} \mathrm{O}$, 二次泩では夫々 $355 \pm 106$ $\mathrm{mmH}_{2} \mathrm{O}, 156 \pm 88 \mathrm{mmH}_{2} \mathrm{O}, 513 \pm 72 \mathrm{mmH}_{2} \mathrm{O}$ であっ た. 治療は血行病態に応し, 直達療法・遠位脾䟝静脈 吻合・硬化療法が選択された。

二次性を血行動態的に診断するため, 閉塞性肝静脈 造影が有効であった。一次性の原因として，腸回転異 常による肝十二指腸靶帯の捻転に起因する門脈閉塞を 経験した。極めて稀と思われるので，あわせて報告し

\begin{tabular}{|c|c|c|c|}
\hline 田頭 & 尚, 加藤 & 倫裕，三村 & 久 \\
\hline 浜崎 & 啓介，柏野 & 博正, 岡林 & 孝引 \\
\hline & 宏, 柚木 & 正行, 古口 & 契児 \\
\hline
\end{tabular}
た。

\section{5. 猪瀬型肝性脳症を呈した porto-systemic shunt 6 例の術前後の循環動態}

岡山大学第 1 外科

我ふは猪瀬型肝性脳症の 5 例を経駼し, portosystemic shunt に対して短絡路閉鎖切除術を施行し,

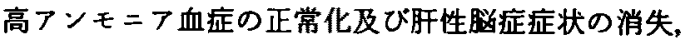
$\mathrm{ICGR}_{15}$ 等肝機能の改善をみた。短絡路は左胃静脈左堅 静脈 3 例，脾静脈左腎静脈 1 例，上下腸間膜静脈左腎

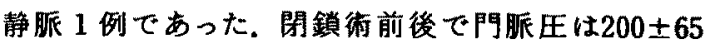
$\mathrm{mmH}_{2} \mathrm{O}$ から $253 \pm 63 \mathrm{mmH}_{2} \mathrm{O}$ へと上昇した。 シャン ト流量は $400 \sim 450 \mathrm{ml} / \mathrm{min}$ と高流量であった。䏕生検 では portal fibrosis 2 例, fibroelastosis 2 例, liver cirrhosis 2 例であった. 街前後の経直腸門眽シャント 
率 (99m-TCO4`)では著明改善を認めた例とほとんど 变化を認めなかった例があった。

\section{Porto-Systemic Shunt 閉鎖症例の検討}

東京女子医科大学消化器病センター外科

$\begin{array}{lrr}\text { 鉿木 } & \text { 隆文, 高崎 健, 済陽 高穂 } \\ \text { 次田 正, 有賀 淳, 宮崎正二郎 } \\ \text { 桂 浩二, 大坪 毅人, 中上 哲雄 } \\ \text { 小林誠一郎, 羽生富士夫 }\end{array}$

肝性脳症慢性型の一つに猪瀬型脳症がある。これは 門脈血の大循環系への直接流入が原因となって起こる とされており，短絡路の閉鎖で症状の改善がみられる ことが報告されている，一方，䀒硬変等の門脈圧六進 状態においても食道静脈瘤のほかに, 脾腎静脈短絡路, 傍脂静脈等の Porto-Systemic shunt を, 形成する側副 血行路が想められることがある。我々は現在までに, 旰硬变に合併した Porto-Systemic shunt が原因で腷 症を起こしたと思われる症例に対し shunt 閉鎖術を施 行し全例に媨症の改善を認め，また一部の症例では肝 機能值の改善るみられた。これらの症例を提示し術後 食道静脈瘤発生について報告する。

\section{7. 胃静脈瘤の成因における短胃動静脈血行動 態の関与}

東京慈恵会医科大学第 2 外科 佐野勝英

目的：短胃動静脈系と胃壁内血行の関係を検討寸る 目的で今回我々は, 胃左上半部の局所的高王状態を雑 種成犬を用い実験的に作製し脾重量，血管造影，短胃 静脈及び胃壁血流測定, 胃病理組織所見につき検討し た.

方法：A群；脾静脈を膵体部で結紮切離のみ。 B 群；A十短胃動静脈のみを保存し左側大網を含め血 管郭清を行引。

結果：1) A 群は 3 日までに側副路の急速な形成が 見られ，B群の短胃静脈血流量は $3 \mathrm{M}$ をて経時的に増 加し以後减少した．胃壁血流量も大弯後壁を中心に 2〜3M まで増加した．2）㑡副路形成は脾，胃底部より 横隔膜，胃腎，脾腎へ，3M からは左胃静脈系へ流失し た. 3）組織学的には，胃底部大弯後壁を中心に，著明 ならっ血状態を示した。

28. 硬化癔法前後の門脈血行動態の検討一門脈 圧，H/L 比による再発予知と再発防止対策
福島県立医科大学第 2 内科

小源 勝敏, 入沢 篤志, 嘉村亜希子

渡部 則也、平原 美孝, 坂本弘明

粕川 禮司

目的：硬化療法 (EIS) 前後の門脈圧と H/L 比の変 化と再発, 地固め法後の門脈正の変化と再発につき検 討した。

対象：EIS 後 1 年以上観察できた肝硬変に伴 5 食道 静脈瘤40例 (EO・AS 併用法の完全消失例で地固め未 施行27例, 地固め法施行13例).

結果：EIS 後の H/L 比上界例には再発を認めず, $\mathrm{H} / \mathrm{L}$ 比無変化一下降例でかつ門脈圧上昇例に再発が 高頻度（83.3\%）にみられた。しかし，地固め法施行 例では門脈圧の変化に関係なく再発を認めていない， 従って, EIS 前とによるEIS 終了時完全消失の門脈王 と H/L 比の変化をみて, 再発が予知された場合は積 極的に地固め法を施行することで，短期再発が防止さ れると考えられる。

\section{9. 経腹的食道離断術後の遗残・再発静脈瘤に} 対する内視鏡的硬化療法による一考察

東京医科齿科大学第 1 外科 井上 晴洋, 五関 謹秀 中村 宏, 遠藤 光夫

自動吻合器（EEA）を用いた経腹的食道離断術後の 遺残・再発静脈瘤に対し, 内視鏡的硬化㞠法を施行し, varicerographyににつて挨討した。硬化剤は全例で食 道側から胃側へ向い, EEAによる離断部を越えて拡 がった。. 特に術後25日目の症例では硬化剂は離断部で 一旦停滞するものの, 続いて離断線を越えて胃上部人 拡がった。このときEUSでる硬化剂は壁内を流れる ことが示された.

したがって EEA による離断部は術後早期から再涷 通している可能性が示された。

以上より術後の遺残・再発静脈瘤に対しては壁内血 行路の遮断を中心とする血管内注入法による硬化療法 の併用が有用と考えられた。

30. 硬化療法で食道静脈瘦の軽快をみた A-P シャントを合併したCruveilhierBaumgarten 症候群の 1 例

聖マリアンナ医科大学第 1 外科, 同 薬剂部 岡野亭, 䒜原優, 中野末広 


$\begin{array}{rrrr}\text { 長岡 } & \text { 至朗, 酒井 } & \text { 昌博, 猪狩 } & \text { 次郎 } \\ \text { 守屋 } & \text { 七布, 滗田 } & \text { 偻, 渡辺 } \\ \text { 清水 晃, 柳川 } & \text { 忠二 }\end{array}$

症例は62歳男性．上腹部王迫感を主訴に来院，腹壁 静脈の雜音を伴ら怒張を認め, CruveilhierBaumgarten 症候群之診断し，同時に食道静脈瘤の合 併をみた。

予防的硬化療法を施行したが改善せず，食道静脈瘤 からの出血があり、S-Bチューブにて止血した。腹部血 管撮影で A-Pシャントがみつかりこれが門脈压六進 の一因と考え右肝動脈塞栓術を施行しさらに硬化療法 を追加し食道静脈瘤の消失をみた。

C-B 症候群の血行動態を含め若干の文献的考察を加 え報告する。

\section{1. 消化管壁との関係より見た側副血行路一超 音波内視鏡に上る壁内壁外血管構築一 九段坂病院外科 \\ 中村 宏，杉原 国扶，三宅 智 安野正道, 高松 督 \\ 東京医科崡科大学第 1 外科 \\ 井上 晴洋, 遠藤 光夫, 五関 謹秀}

超音波内視鏡(EUS：Olympus GF.UM3, 7.5MHz, ラシフル型)を用い消化管を中心とした壁構造，壁外 血管像を橎察し，血管造影で描出し得た門脈圧六進症 側副血行路と内視鏡的にみられる食道胃静脈瘤との関 係を検討した。

結果：食道静脈瘤の多くは噴門部より壁外血管が流 入し食道壁内の静脈瘤を形成していた。胃静脈㾴まで 発達の著しいるのは，胃上部において多数の血管を供 血路としていた，孤立性胃静脈瘤の 1 例は胃壁内に流 入しない左胃静脈腎静脈シャントであった。また内視 鏡上は全く静脈瘤を見なくても発達した脾静脈堅静脈 シャントを有する例す見られた。

結語：食道胃静脈瘤の病態解明には, EUS に上る消 化管壁内壁外血管構造の把握が重要である.

\section{MRIによる門脈血行動態の評価}

埼玉医科大学第 1 外科

駒崎 敏郎，鉫柄 稔，尾本 良三

同放射線科 天沼 誠, 平田 寿 長谷川 真, 平敷 淳子

MR フンギオダラフィー (MRA)を用いて門脈圧立
進症例の門脈血行動態を評価した. MRA で門脈本幹, 脾静脈, 左胃静脈, 短胃静脈, 後胃静脈, Porto-systemic shuntを検索し、門脈造影と比較した。使用装置はシー メンス社製マグネトム(1.5テスラ)である。門脈本幹， 脾静脈, 側副血行路は全て,MRA と門脈造影と一致し た所見を得られた。MRA は造影剂を全く用いないで， 血流を視覚化できる画期的なテクンックである．血管 内腔を画像化しているのではなく，血流をイメーシと して捉えているため, 解剖学的な情報に加えて, 機能 的な情報もある程度反映され，復雑な血行動態を示す 門脈仕穴進症の評価法として有用であった。

\section{3. 門脈圧え進症における脾静脈血行動龍の検} 討

\section{日本医科大学第 1 外科}

吉田寞, 恩田 昌彦, 田尻 孝 梅原松臣, 真々田裕宏, 山下 精彦 金德栄, 鳥羽 昌仁, 足立 幹夫 西久保秀紀, 谷合 信彦

Scintiphoto Splenoportography (SSP) と血管造影 とを組合せ，門脈血に占める脾静脈血の割合 (SV\%) を計測する方法を考案し，原疾患別に算出して門脈血 行動態を検索した。

对象：SSP，血管造影を併施し分析可能であった無 治療症例90例。脾静脈からの側副血行路の有無で, I 群：無, II群：有，に分類.

方法：SV\%は, 単位血管体積当りの(門脈 count) $\div$ (脾静脈 count) $\times 100$ で求る.

結果：正常対照15.8土4.9が有意に低く，次に肝硬变 II 群 $24.3 \pm 21.4$, 次に訮硬変 I 群 $47.0 \pm 18.0$ および慢

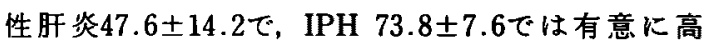
かった。慢性肝炎，肝硬变，IPHに打ける脾領域の local hyperdynamic state の存在が示唆された.

\section{4. 食道静脈痽圧測定の意義}

東京大学第 2 外科

柴崎 正幸, 三條 健昌, 万代 恭嗣

今村宏, 野村 幸博, 張 紹泰

平田勝, 皆川 正已, 橋本 雅司

大橋 一雅, 川崎 誠治, 出月 康夫

1986年より現在まで食道静脈瘤王の測定を行った55 例を対象として, 食道静脈㴛王と他の門脈血行動態の 指標との相関，及び内視鏡所見，予後との関連を検討 
$80: 976$

した.

55例に対し合計105回の食道静脈瘤圧の測定を行い，

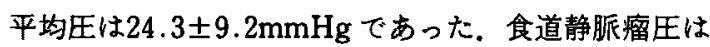
閉塞肝静脈圧と有意の相関を示し，とくに同時測定例 ではほぼ等しい値を示した，しかし，血管造影におけ る上行性側副血行の発達の程度及びその定量的指標の 1 つである奇静脈血流量とは有意の相関を認めなかっ た.内視鏡所見では発赤所見陽性例で有意に圧は高く， また硬化療法難治例も圧は高い傾向が認められ，臣の 面からある程度予後を予測することが可能と思われ た。

\section{5. 慢性肝疾患における門脈血流変動の検討} 東京慈恵会医科大学第 1 内科

空閑 和人, 鴨下 宏海, 関谷又一郎
新井
豊彦, 戸島恭一郎, 植松 幹雄
樺
今恵, 山崎 一信, 石沢 和敬
深, 串田 治男

目的：慢性肝疾患における門脈血流量変動の差異を 明らかにするために，超音波バルスドッブラー法によ り, 慢性肝炎, 肝硬変症の門脈血流量の日内变動を比 較検討した。

対象および方法：肝硬変应，慢性肝炎について，毎 食前及び食後 2 時間の門脈血流量を超音波バルスドッ ブラー法（東芝 SONOLAYER $\alpha$ SSA.270A）により 测定した。

結果及び結論：肝硬変症では，毎食後 2 時間の門脈 血流量の増加率は約 $30 \%$ で慢性肝炎の $40 \%$ に比へ，低 值をしめしたが，昼及び夕食前は，朝食前值まで低下 せず，夕食後 2 時間値では約 $75 \%$ の增加を認めた。肝 硬变症では，食事摄取による血流量増加が逶延し慢性 肝炎とは異なる变動を呈すると考えられた。

36. 門脈圧元進症における超音波ドップラー法 によろ門脈血流量測定の意義 北大第 2 外科

中島 公博，加藤 紘之，池永 治親 金谷聡一郎，中村 豊，奥芝 俊一 児嶋 哲文, 下沢 英二, 田辺 達三

門脈圧六進症治療例に対する超音波ドップラー法の 意義について検討した，対象は選択的遠位脾腎静脈吻 合術の10例である。観察部位は門脈本幹，門脈右枝， 左枝, 脾静脈, 上腸間膜静脈とし, 術前おょび術後に
行った，血流量は血流速度，血管断面積から計算式に 上って求めた。衍前の ICG K 值と門脈血流速度は相関 する傾向を示した，また術前の門脈血流量は645.6ml/ $\min$ であったのに対して術後は $398.3 \mathrm{~m} l / \mathrm{min}$ と約 60\%に減少していた。

超音波ドッブラー法は門脈圧え進症に対するシャン 卜術前後の門脈血行動態を把握するために重要であ り，術後経過観察のための有用な検査法の一つである と考えられた。

37. 門脈圧六進状態における副側血行路の把握 に対する超音波パルスドプラー法の有用性 阿知須同底院内科田道 若子 山口大学第 1 内科

国立下関病院内科

$$
\text { 田邊 一郎, 沖田極 }
$$

松田 彰史, 原田 俊則

要旨：超音波パルスドブラー法を副側血行路の把握 に用いるにあたり，不安があると考えられてきた計測 値の信頼性を門脈本幹，上腸間膜静脈，脾静脈の 3 者 について，いわゆる連続の法則を適用して検定したと ころ，対象とした健常者11例，慢性肝炎18例いずれに む連続の法則が成り立ち，測定値はほ洼满足しらる精 度と考之られた，一方，肝硬变14例では，門脈本幹か らの副側血行路の存在が示唆される結果であった。 た, 脾静脈の脾門部と膵尾部背側との血流量を比較し えた10例の肝硬変のらち，膵尾部で著しい血流低下を 認めた 5 例には， RC sign（+）ないし Lg (+)の食 道静脈瘤が確認でき，この分野に対して，ハハスドブ ラー法が有用と考えられた。

\section{8. 門脈圧元進症と循罩動態: Color Doppler-EUS を用いた上行性側副血行路の 検討}

昭和大学第 2 内科, 同 外科*

富士吉田市立病院内科**

西田 均, 高橋正一郎***米山啓一郎
小貫
誠, 川内 章裕 ${ }^{*}$, 八田 善夫

超音波内視鏡（EUS）とドブラ断層法（Color Doppler echography）を併用した Color Doppler-EUS (CD-EUS)により，消化管周囲の脈管の同定，血流方 向，速度等の検出が可能となった，今回，門脈任六進 症31例，コントロール10例における胃，食道壁内，壁 
外，奇静脈血流の検討を行い，以下の結果を得た，1） F因子と壁外血流は必ずしも一致しない，2）胃壁内血 流は高頻度に食道静脈膚と連続していた，3）門脈圧え 進症で奇静脈は执張し流速す増加し，屈曲部より口側 まで連続していた，4）壁内，外，奇静脈血流波形は定 常流あるいは拍動流を呈した，5）CD-EUSにより門 眽压亢進症における上行性側副血行路の検討が可能 で，循環動態の解明に有用と考えられた。

\section{9. 明らかな側副血行路を認めない特発性門脈 圧元進症の 1 例 \\ 北海道大学第 3 内科 \\ 林下 尚之, 吉田 純一, 目黒 高志 \\ 恢賀 啓良, 松嶋喬, 宮摘保}

特発性門脈圧元進应(以下, IPH)は脾腫，貟血，門 眽圧え進症などの症状を呈するが，これらが出現する 経過については不明の点が多い，今回，我々は著明な 脾腫と門脈圧の亢進を認めるも，経皮経肝門脈造影を 含めた種々の画像診断において門脈系に明らかな側副 血行路形成を確諗しえず，白血球と血小板の減少を 伴った症例を経鞈しIPH と診断したＩPH の病態を 知る上で，この様な症例を検討することは重要である と考えられ、この症例を含め最近, 当科において診断 しえたIPH 4 例と,脾腫をとすな5肝硬变症および血 液矣患患者それぞれ，26例，12例について超音波バ スドブラを中心とした門脈血行動態を検討し報告し た.

40. 脾摘後門脈血栓を来した 1 例 国立長崎中央病院外科

山田 雅史, 古川 正人, 中田 俊則 草野 敏臣, 渡部誠一郎, 王志明 古賀 浩孝, 永尾 修二, 㙃本浩 伊藤実枝子
特発性門脈王元進症による脾腫及び沉血球减少症を 認めた54藏の女性に対し, 平成 2 年 4 月に脾摘街を施 行した，血小板は術前の 4 万台から術直後急速に増加 し，10日目には40万台となり現在に至っている. 逨後 上り認めた $38^{\circ} \mathrm{C}$ 前後の発熱が遷延し，一過性の肝機能 障害む出現した，本例に打いて，手術前後に超音波ハ ルスドッブラー法を用い，各門脈血流量を測定し種々 の病態を検討した。その結果，術後門脈本幹から門脈 左枝 (腈静脈部) にかけて血栓を認め, 門脈血流も測 定できないほどに减少していた，血栓形成の要因とし て, 血小板の增加と共に, 脾摘に上る肝内門脈微小血 栓の形成, 門脈血流量低下による門脈血栓増悪などが 示唆された。

41. Thioacetamide (TAA) によるラット肝硬 変モデルの循環動態と膵クルカゴン及びイン シュリンの解析

京都府立医科大学第 3 内科

垭 直樹, 岡上 武

肝硬変での高グルガンン及び高インシュリン血症の 原因として，これらのホルモンの肝での代謝の変化と 循環動態の異常と関連性が指摘されている.我々は TAAによるラット肝硬変モデルを用い, Radioactive Microsphere Methodにより全身及び腹部血行動態を 解析し, 両ホルモンの門脈及び大眼動脈での血中瀑度 を測定し検討した１１：TAA 投与による肝硬変ラッ トでは門脈王穴進と門脈一体循環シャントの出現, 門 眽及び全身血流の hyperdynamic stateを認めた。 2 : 肝硬竻ラットでは高クルカゴン及び高インシンリ ン血症が存在し, 前者は膵からのグルカコン分泌过隹 が主因であり，後者はインシュリンの肝での代謝の低 下がその原因であると思われた。

\section{主題II シンポジゥム「門脈圧え進症と循環動態」}

42. 門胉圧え進症における脾厘の門脈圧に及は す影霎について

東北大学第 1 外科

松原 鉿木 正德
大内 清昭, 松野 正紀

目的：門方症における腪腫の臨床的意義について, 脾重量と門脈圧の面より食道静脈瘤手術例中の脾摘垪 施例で検討を行った。

方法および成績：肝硬変症62例，IPH 42例，肝外門 
脈閉塞症14例を対象とした，脾重量 $500 \mathrm{~g}$ 以上を巨脾 群，それ以下を非巨脾群とした．肝硬变症の巨脾例は 非巨脾例に比して, ICG R 値は有意に高値を示した か，この傾向は他の 2 疾患では認められなかった。門 眽王は，巨脾，非巨脾で有意差は認められないが，肝 外門脈閉塞症は他の 2 疾患に比べ有意に高值を示し た。脾摘に上る門脈の減王率は，肝外門脈閉塞症が他 の 2 疾患に比して有意に高い減圧率を示した。さらに IPH および肝外門脈閉塞症では肝硬変に比べ, 有意に 巨脾群が非巨脾群に比べ高い減圧率を示した。

\section{3. 巨大シャント例におけるアンモニア及ひ胆 汁酸代謝}

順天堂大学第 2 外科

神田 博司, 丸山 俊朗, 奥山 耕一
中西 亮, 渡辺 勇, 览島 邦明
木下 榮一, 深沢 正樹, 別府 倫兄
二川 俊二

私共は従来より門脈圧元進症の肝外ンャントの指摽 として, 肝静脈カテーテル法施行時に肝静脈及び大循 環血中のアンモニアを測定してきた．今回同時に採血 した胆汁酸濃度と比較検討した結果, ICG- $\mathrm{R}_{15}$ との相 関は，フンモニフでは下大静脈血より肝静脈血で, 胆 汁酸では肝静脈血より下大静脈血で，上り緊密な相関 が認められた。 大循環血においては, アンモニフは肝 以外の代謝に影響され，胆计酸は肝クリフランスと共 に肝外シャントが反映されるためと推測された。 また， 肝静脈血中アンモ二ア値の上昇は，肝内シャントの関 与が推測された。門脈循環の部位により異なるが，血 中アンモニアと胆汁酸は，それぞれ肝外シャントの指 標として有用と考えられた。

\section{4. 肝硬変症における全身循環方進状態への高 estrogen 血症の関与に関する実験的検討}

藤田学園保健衛生大学消化器外科

橋村 宏一, 青木 春夫, 蓮見 昭武

島津 元秀, 吉松 泰彦, 林収

金田 友之，木村 彰良

肝硬変症における高 estrogen 血症が胃壁粘膜下 AVAの開大要因の一つとして食道・胃静脈瘤発生に 関与していることは既に報告したか，今回は肝硬変症 における高 estrogen 血症の全身循環方進状態への関 与につ妾Wistar 系雄 rat を用いて㬰験的に検討し
た.

心拍出量は, 対照群 $(\mathrm{n}=13)$ の $118.6 \mathrm{~m} l / \mathrm{min}$ K比し, 肝硬変作成 $\left(\mathrm{CCl}_{4}\right.$ 法) 群 $(\mathrm{n}=8)$ では164.1, estrogen 投与群 $(n=5)$ では223.8と有意 $(\mathrm{p}<0.01)$ に增加し, 肝硬変作成+estrogen 投与群 $(\mathrm{n}=6)$ では234.1と胢硬 変作成群よりるさらに有意 $(\mathrm{p}<0.01)$ に増加してい た. 従って肝硬変症における高 estrogen 血症は, 胃壁 のみならず全身循環に対しても六進の要因の一つとし て関与していることが確認された。

\section{5. 肝硬変性門脈圧立進症における膵クルカゴ} ン動態と胃壁循環異常に及ほす影響 大分医科大学第 1 外科 吉田 隆典, 御手洗義信, 板東登志雄 中島 公洋, 吉村 高尚, 長峰 健二 小林 迪夫

肝硬変性門脈王六進症 (門元症) の腈グルガン （IRG）動態を検討し，胃壁循環方進状態の面からみた IRGの意義について報告した。門六症30例と対照12例 を対象とした. IRGの産生量と代謝量を算出, IRG 動 態を明らかにした。さらに胃壁循環動態を測定, 動脈 血 IRG 濃度との関連を恰討した.ささらに高クルカゴン 血症ハムスターを用いて実験的検討を加えた，その結 果, 門六症では IRG 産生量增加による高 IRG 血症を 示し，これには自律神経系，特に交感神経系の関与が 示唆された。また門え应の胃壁における循環六進状態 発生の要因として IRGは重要な地位を占めるものと 考えられた。

\section{Nitroglycerin (NTG)の門脈血行動態にお よほす影響}

久留米大学第 2 内科

岩尾 忠, 豊永 純, 角野 通弘

高木 孝輔, 大久保和典, 井上林太郎

谷川 久-

$\mathrm{NTG}(1 \mu \mathrm{g} / \mathrm{min} / \mathrm{kg})$ の門脈血行動態に及ぼす影響 について検討するため，15例の肝硬変症患者(NTG 9 例, Placebo 6例)に一連の血行動熊検查を施行し，以 下の結果を得た. Placeboは血行動態成績に影響を与 えなかったが，NTG 投与により平均血圧 $(-26 \%, p<$ $0.01)$ 並びに門脈圧 $(-29 \%, \mathrm{p}<0.01)$ は有意に低下 し, 両者の間に正の相関 $(\mathrm{r}=0.64, \mathrm{p}<0.01)$ を認め た。肝血流量は変化がなかった，以上より，䀒血流量 
を維持しつつ門脈圧を下降させるNTGは臨床的に有 用と思われた。しかしながら，体血压の低下を防止す る意味からVasoconstrictorとの併用における検討 が，さらに考慮されるべきであると思われた。

\section{PTPによる胃静脈瘤血行動態の検討} 千葉大学第 1 内科

$\begin{array}{lrl}\text { 石井 浩, 松谷 } & \text { 正一 } \\ \text { 古瀬 } & \text { 純司, 大藤 } & \text { 正雄 }\end{array}$

胃底部の結節状胃静脈瘤（LC 23例，IPH 5 例）の 血行動態を経皮経肝門脈造影 (PTP)を用いて検討し た。このような孤立性胃静脈瘤症例に招いては，倒副 血行路の発達は高度であり，また28例中26例（93\%） で高度に発達した腎静脈短絡路を形成していた，胃静 眽瘤を形成する血行路は，後胃・短胃静脈が関与する 症例が23例（82\%）と高率であり，胃静脈瘤の血管構 筑上の特徵之考兄られた。左胃静脈の発達は14例 （50\%)にみられたか，選択的造影の検討から孤立性胃 静脈瘤の形成に左胃静脈が関与寸る症例は 5 例と低率 であった，後胃・短胃静眽優位型の胃静脈瘤において 脾静脈血流方向を検討したところ，23例中16例(70\%) は脾静脈血流方向は順流であった，順流型は胃静脈瘤 血流が比較的軽度と考之られ，逆流型に比べ静脈瘤出 血率も低い傾向であった。

\section{8. 食道静脈瘤症例の門脈域分水嶺} 新潟大学第 1 外科

塚田一博, 長谷川 滋, 加藤 英雄
土屋 嘉昭, 清木 武昭, 吉田 奎介
武藤 輝一

食道静脈瘤が存在して門脈が求肝性に流れる場合門 脈域には二つの流出か存在することになる。この二つ の分流点を胃全摘後症例（58歳男性）に於て確認しこ れが通常の食道静脈㿔症例においてる適応出来るるの
之考之門脈域分水嵿と表現した，今回 VASOPRESSIN(VP), NITROGLYCERIN(NTG), PROSTAGLANDINE 1 (PG) 投与で分水嶺の変動を見た。

結果：VPでは一過性の門脈正低下，NTGでは約 23\%の聞脈圧低下をみたが分水嶺に变化はなかった。 PG では門脈王に変化法認めないにるかかわらず分办

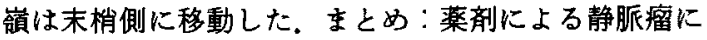
対する効果を判定する場合門脈圧や流量の变動だけで は不十分であることが示唆され，こうした面からす門 脈域分水嶺の検討は重要である。

\section{9. 実験的門脈圧え進症における肝内血行動態} の検討

秋田大学第 1 外科

$$
\begin{array}{llll}
\text { 面川 進, 古屋 } & \text { 智規, 伊藤 } & \text { 正直 } \\
\text { 白山 公幸, 佐藤 } & \text { 敬文, 新井 善雄 } \\
\text { 浅沼 義博, 小山 研二 } &
\end{array}
$$

目的：門脈遮断後の肝内門脈血行動態及び遠肝性副 血行路遮断の意義の検討

方法：脾臓皮下固着ラットの門脈結紫群と, 門脈結 紮 1 週後に遠肝性副血行路を遮断する群で肝外門脈 压，門脈終末枝圧（TPVP），中心静脈压 (CVP)，肝 組織血流量, 門脈造影像を検討した。

成績：肝外門脈圧：副血行路遮断群ではより門脈圧 元進が維持された。 TPVP, TPVP-CVP 压較差：門脈 結柴直後の低下は 4 週で前值に回復した。副血行路遮 断群ではより早期に回復した，肝組織血流量：副血行 路遮断群で早期に回復した、門脈造影像：副血行路遮 断群では，求肝性副血行路の形成は早期で著明であっ た。

結語：肝外門脈閉塞症では, 副血行路遮断による求 肝性副血行路の形成促進により肝内門脈血行動態が早 期に改善される.

\section{主題 I シンポジゥム「食道静脈瘤治療の予後」}

\section{0. 食道静脈瘫硬化癔法900症例の検討}

九州大学医学部第 2 外科

$$
\text { 橋爪誠, 田上和夫, 太田 正之 }
$$$$
\text { 北野 正剛, 杉町 圭蔵 }
$$

硬化療法の予後を明らかにする目的で，本年 5 月李 でに食道静脈瘤の完全消失を達成し得た719例につい て倹討したので報告する。

急性例は116例，待期例173例，予防例430例で，急性 出血の止血率は $100 \%$ であった。静脈瘤の完全消失達成 
率は79.9\%で，消失までに平均 4.4 回，入院は平均 6.3 週間であった。主な合併症として食道潰瘍出血，腎不 全，华下障害，胃炎出血等が認められた。治療後の社 会復帰率は普通生活が可能な患者で88.3\%であった， 5 年生存率は Child A $80.6 \%$, Child B $62.2 \%$, Child

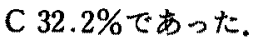

以上ょり，硬化療法は従来の治潦法係色なく，治 療後の社会復㷌率も高く，予後は良好であると考えら れた。

\section{1. 再発防止からみた食道静脈瘦治療法の選択} 一quality of life を考慮にいれて一

福島県立医科大学第 2 内科

坂本 弘明, 小原 勝敏, 入澤 篤志 桑名 俊光，渡部 則也，平原 美孝

森藤 隆夫，粕川 軆司

当科では現在まで234例に内視鏡的食道静脈瘤硬化 療法を施行し，食道下部飞全周性に AS を注入し線稚 化させる AS 地固め法が再発予防に非常に有効である ことをすでに報告した。 しかし治療期間が 2 力月以上 と長期間であり患者の quality of life を考虑すると， AS 地固め法す全例に施行するのではなく，再発しゃ すい例，または短期間のちちに再発したものについて のみこの療法を追加するようにすれば治療期間の短樎 が可能と考えられる。立た手術療法との併用療法に関 しては, 肝硬変では硬化寮法難治例のみであり，IPH ではEISあるいは Hassab 手術単独よりる併用療法 が有効であった。

\section{2. 食道静脈癐出血に対する直達手術の遠隔成 績}

\section{愛知医科大学第 1 外科}

河合 痛化, 山本 貞博, 竹重 言人 黑田 博文, 鉿木 寛路, 長谷川 誠 田中 信臣, 神谷宏, 田中一正 坂野 耕司, 小林 秀雄, 宮下 章

1975年からの15年間に門脈王六進症371例を程験し， Child A 群84例中64，B 群159例中104例，C 群128例中 40例に直達手術を適用 ᄂ，硬化療法江手術適応基準外 症例または緊急出血例の32例に適用し,PTOを11例に 施行した。肝癌非合併静脈瘤出血例に対する直達術後

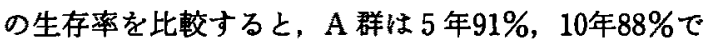
あり，B 群の 5 年 $63 \%, 10$ 年 $46 \%, \mathrm{C}$ 群の 5 年 $36 \%, 10$
年 $26 \%$ に比べて良好であったが，再出血率は，A 群 5 年 $10 \%, 10$ 年 $14 \%, \mathrm{~B}$ 群 5 年 $18 \%, 10$ 年 $41 \%, \mathrm{C}$ 群 5 年 $29 \% ， 10$ 年 $29 \%$ で，有意差はなかった，未出血経過観 察の 134 例の出血率は，5年 $28 \% ， 10$ 年31\%で，生存率 に及ぼす影響は少なく，予防的治療は，慎重に適用す べきことが示唆された。

\section{3. 胃上部切除術後の長期予後}

名古屋大学第 2 外科

$\begin{array}{lrrr}\text { 原田 } & \text { 明生, 野浪 } & \text { 敏明, 加藤 } & \text { 秀幸 } \\ \text { 一色 } & \text { 浩一, 伊藤 } & \text { 公一, 伊藤 } & \text { 隆文 } \\ \text { 黒川 } & \text { 剛, 竹田 } & \text { 伸, 氏田 } & \text { 剛 } \\ \text { 村上 } & \text { 裕哉, 赤座 } & \text { 薁, 小林 } & \text { 裕幸 } \\ \text { 鳥井 } & \text { 彰人, 蜂須賀文博, 沈 } & \text { 世強 } \\ \text { 岸本 } & \text { 若彦, 中尾 } & \text { 昭公, 高木 } & \text { 弘 }\end{array}$

最近18年間に施行した胃上部切除術194例の 5 年, 10 年累積生存率はそれぞれ $72 \% ， 55 \%$ と良好であっだ。 静脈瘤再発に対して内視鏡硬化療法を行った症例を除 いた Child 分類別の生存率では Child A 群は B，C群 に比べて有意に良好であった。 またChild C 群の 5 年 生存率は54\%であった。衍後愁訴として胸やけ，つか 光感を約 $15 \%$ に認めたがいずれも軽度であった. Child $\mathrm{C}$ 症例では特に術後 5 年以降再出血例が増加していた が硬化療法の併用により生存率は改善した，㗨急出血 例に対しては硬化㞠法を第一選択として拁り，その止 血率は96\%で一部は待期手術可能となった。

\section{5. 食道静脈瘤に対するシャント手術の長期予} 後の検討

北海道大学医学部第 2 外科

$$
\begin{aligned}
& \text { 金谷聡一郎, 加藤 紘之, 中島 公博 } \\
& \text { 中村 豊, 奥芝 俊一, 児嶋 哲文 } \\
& \text { 下沢 英二, 田辺 達三 }
\end{aligned}
$$

1983年以降の当科に和ける食道静脈瘤に对する DSRS with SPGD 症例50例を対象に，遠隔成綪を中心 に報告する。

内訳は, Child A 群33例，B 群15例，C群 2 例で，平 均追跡期間は 3 年11力月，追跡率は $90 \%$ である。 3 年. 5 年累皘再出血率は $3.3 \%, 3$ 年 5 年果積生存率は 88\%であった，遠隔期の生活状況では，腹部不定愁訴 を $32 \% に$ 認めたが，術後遠隔時の体重変化では，不変 ～増加例が $74 \%$ を占め, 社会復帰率も74\%と良好で あった。 
これらの良好結果は，本術式の門脈・肝血流の長期 的な維持が深く関与しているためと思われた。

\section{6. 硬化療法と手術療法の合併療法施行症例の} 検討

兵庫医科大学第 2 外科
芦田 寛, 長田 哲雄, 福田 正春
高木 一光, 西岡 昭彦, 田淵 正人
橋本 直樹, 琴浦 義尚, 宇都宮譲二

硬化㞠法 (ST) を臨床導入して以来，その最大の目 的は㗨急出血例の止血を目的として扰り，教室では約 65\%の症例が緊急 ST 例である.今回は, ST と手術療 法の合併療法を施行した51例（遠位脾腎静脈吻合33 例・経腹的食道離断 9 例 - Hassab 8 例 - その他 1 例) につき検討した。 45例(88.2\%)が緊急ST 例であった。 ST 後手術までの期間は平均158日であったが，90日以 上（最高1,994日）の症例が10例含まれている.ST 後 肝機能改善例に対する手術療法の予後は比較的良好と 言えたが，肝機能非改善例で法術直死 1 例・術後早期 肝不全 1 例を含め，手術療法付加の再検討が必要と言 えた。街後静脈瘤再発例にたいしてはST が効果的で あった。
57. 硬化療法後の剖検例における静脈瘤内血栓 形成の広がり

久留米大学第 1 病理

荒川 正博, 鹿毛 政義

同 第 2 内科

角野 通弘，高木 孝輔，大久保和典

井上林太郎, 豊永 純

硬化寮法後の再発として atypical red color sign 等 の表層の小血管の静脈瘤化が注目されている。そこで, 我々はこれらの再発がどの様にして生じるかについて 検討を行った．検討症例は $5 \%$ EOにより硬化療法が 施行され，2 カ月以上生存した18剖検例である. 方法 は胃噴門部，すだれ様血管走行部，静脈瘤部からそれ ぞれ標本を作製し，粘膜固有層，粘膜下層に分けて静 脈瘤内の血栓形成の状態を観察した。 その結果は静脈 瘤部の粘膜下層では満足のいく血栓形成がみられるも のの粘膜固有層では少なくむしろ拡張した静脈が認め られた，すたれ様血管走行部でるこの傾向があり，硬 化療法後に副血行路の改变が生じなかった例では粘瞙 固有層に血流が增し，再発が起こり易いことが推察さ れた。 